\title{
Strategic Regional Integration
}

\author{
Kjetil Bjorvatn, Nicola D. Coniglio, Hiroshi Kurata
}

SERIES Working PAPERS N. 07/2016

SERIES sono pubblicati a cura del Dipartimento di Scienze economiche e metodi matematici dell'Università degli Studi di Bari "Aldo Moro". I lavori riflettono esclusivamente le opinioni degli autori e non impegnano la responsabilità del Dipartimento. SERIES vogliono promuovere la circolazione di studi ancora preliminari e incompleti, per suscitare commenti critici e suggerimenti. Si richiede di tener conto della natura provvisoria dei lavori per eventuali citazioni o per ogni altro uso.
SERIES are published under the auspices of the Department of Economics of the University of Bari. Any opinions expressed here are those of the authors and not those of the Department. Often SERIES divulge preliminary or incomplete work, circulated to favor discussion and comment. Citation and use of these paper should consider their provisional character. 


\title{
Strategic Regional Integration
}

\author{
Kjetil Bjorvatn, Nicola D. Coniglio, Hiroshi Kurata
}

\begin{abstract}
We analyze the impact of globalization on the incentive to strengthen regional integration. In a simple three-country oligopolistic trade model, we demonstrate that increased external competitive pressure may induce governments, influenced by producer interests, to lower intra-regional trade costs in order to mitigate the effects of external competition on local businesses.
\end{abstract}

Keywords: Regional integration; Globalization; Cournot competition JEL classifications: F12, F15, F6 


\section{Introduction}

The last two decades have witnessed a rapid increase in regional trade agreements (RTAs). This trend of increasing regionalization of the world economy is proceeding hand in hand with the progressive reduction of barriers to international trade in goods and services across the globe.

The existing literature on RTAs has highlighted several reasons why RTAs emerge: (i) to internalize negative policy externalities such as beggar-thyneighbor trade policies (Ossa, 2010); (ii) to function as credibility device and limit time-inconsistency in trade policies (Maggi and Rodriguez-Clare 1998); (iii) to exploit internal-market economies of scale or increase attractiveness for inward FDI; (iv) to serve political goals (Capling, 2008; White, 2005); (v) as a result of a contagion or domino effect (Baldwin, 1995); or (vi) to serve as potential building blocks to further global integration (Bhagwati, 1992; Baldwin, 2006).

In this paper, we emphasize an alternative reason for the formation and deepening of RTAs focusing on strategic interactions in international oligopolistic markets in the context of globalization. In a simple, threecountry model with oligopolistic firms, we show that regional governments may choose to reduce intra-regional trade barriers in order to discourage a foreign competitor from entering the market. In this way, regional integration is an alternative to protectionistic policies, which may not be available due to multilateral trade agreements. Our model thus sheds light on the observed surge of negotiations between advanced economies toward a deepening of regional trade agreements such as the EU-USA Free Trade Agreement and the Trans-Pacific Partnership which involves Japan and the USA among other countries. These agreements typically exclude emerging countries such as 
China and are strongly backed by powerful lobbies of large firms operating in oligopolistic sectors.

Producer interests have been found to be an important factor in shaping policies of regional integration. Large firms spend millions of US dollar in order to lobby for regional trade agreements. For instance, large corporations in the US increased their spending in federal lobbying for pushing the Trans Pacific Partnership (TPP) trade deal (Martyn 2016). In a recent work documenting business advocacy and lobbying for trade deals, Solis (2013) documents the determinants of active corporate lobbying in preferential trade agreements (PTAs) in Japan, emphasizing the importance of "defensive lobbying" in this context. The largest Japanese business lobbying group Keidanren has actively advocated the TPP trade agreement and further liberalization efforts with the EU while it has not backed a trade agreement with Japan's largest trade partner, China. In fact, Keidanren has a very defensive stance vis-à-vis China and it is interesting to note that both prime ministers Koizumi and Abe have publicly labelled TPP a tool for balancing against the rise of China in the East Asian economic space (Terada 2010).

In a related paper, Neary (2004) investigates the effects of a reduction in intra-regional trade costs vis-à-vis international trade costs on the strategic choice of a foreign multinational regarding whether to serve the regional market through export or by means of single or multi-plant FDI. Like us, he focuses on a partial equilibrium setting where oligopolistic, domestic firms compete with a foreign multinational. In his setting a sufficiently high reduction of intra-regional trade costs might shield the domestic market from the competition of the foreign multinational; a 'fortress Europe' type of effect. But the focus of our papers is different. While Neary (2004) addresses 
the entry strategies of a foreign multinational for a given level of regional integration, we endogenize regional integration, taking the entry strategy of the foreign firm as given.

Our paper is also related to the literature on the sustainability of tradingblocs and on the external effects of customs unions. Freund (2000) investigates the effect of multilateral trade liberalization on the sustainability of preferential trade agreements. Bond et al. (2001) analyze how bilateral integration can increase the sustainability of a multilateral tariff agreement. An important feature distinguishing the present contribution from the related literature is that we focus on how differences in the competitiveness of the outside firm affect the incentive to deepen the regional integration, while in the other models firms are typically assumed to be symmetric.

The rest of this paper is organized as follows. Section 2 outlines the basic setup for our analysis. Section 3 analyzes the case for strategic

regionalization as the result of global competition. Section 4 provides brief concluding remarks.

\section{Model}

Consider a region consisting of two identical countries. Each country has a single domestic firm, which we refer to as a regional firm. The firms are immobile, and markets are segmented. The inverse demand function in each market is given by

$$
p=1-X,
$$

where $p$ is the price of the good and $X$ is the market demand. Firms must incur intra-regional trade costs, $t$, when exporting between countries, while marginal production costs are normalized to zero. We refer to a reduction in 
$t$ as regional integration.

In the initial state, which we refer to as pre-globalization, the region has no trade with the outside world, possibly due to prohibitively high extra-regional trade costs. In a subsequent phase, which we refer to as globalization, the region starts trade with a foreign country.

\subsection{Pre-globalization}

In the pre-globalization phase, countries in the region face no external competition from third countries. Define $\pi_{R}$ as a firm's profits from sales in the region, derived from sales to the home market (subscript $H$ ) and to the neighboring market (subscript $N$ ). Profits are thus given by:

$$
\pi_{R}=p_{H} x_{H}+\left(p_{N}-t\right) x_{N},
$$

Using the inverse demand function (1), we can derive duopoly profits (indicated by superscript $D$ ) under Nash-equilibrium as:

$$
\pi_{R}^{D}=\frac{(1+t)^{2}}{9}+\frac{(1-2 t)^{2}}{9}
$$

Note that from (3), intra-regional exports are profitable as long as $t<\frac{1}{2}$. If $t \geqslant \frac{1}{2}$, the two firms operate in autarky. If so, each firm generates monopoly profits (superscript $M$ ) given by:

$$
\pi^{M}=\frac{1}{4}
$$

Figure 1 illustrates how profits depend on the level of intra-regional trade costs. We note that prohibitively high intra-regional trade costs generate higher profits for both firms compared to full regional integration, i.e., $t=0$. Besides these extreme cases, the effect of deeper regional integration on profits depends on the initial level of trade costs. In fact, a reduction in internal 
trade barriers brings into action a trade-off between the negative effect of $i n$ creased competition and the positive market expansion effect (Viner, 1950). In our model, for initial trade costs greater than $2 / 5$, deeper regional integration is always bad for producers, while for initial trade costs less than $2 / 5$, deeper regional integration may be good for producers, if the reduction is sufficiently large. For initial trade costs less than $1 / 5$, deeper regional integration is necessarily good for producers.

\subsection{Globalization}

We model the globalization scenario in a simple way by considering the integration of a new country. We abstract from globalization as a source of demand for the regional firms; inclusion of this aspect will in fact not alter the costs and benefits of regional integration.

The new country, country $F$ (for foreign), is home to a firm that produces the same homogeneous good as the regional firms. The sales cost of the foreign firm when exporting to the region (inclusive of trade costs) is given by $c$.

The equilibrium triopoly profits (indicated by superscript $T$ ) for a regional firm in the globalized scenario (indicated by a hat) are given by:

$$
\hat{\pi}_{R}^{T}=\hat{\pi}_{H}^{T}+\hat{\pi}_{N}^{T}=\frac{(1+t+c)^{2}}{16}+\frac{(1-3 t+c)^{2}}{16} .
$$

where the first term on the right hand side is profits from sales in home country and the second term is profits from sales to neighboring country.

The profits of the foreign firm under triopoly is given by:

$$
\hat{\pi}_{F}^{T}=\frac{2(1-3 c+t)^{2}}{16} .
$$

Importantly, we see that exports from the foreign firm are profitable if:

$$
\hat{\pi}_{F}^{T} \geqslant 0 \Rightarrow t \geqslant 3 c-1 \equiv t^{*}
$$


so that intra-regional trade costs at or below $t^{*}$ would not make it profitable for the foreign firm to enter the market.

The entry of a foreign firm may make intra-regional trade unprofitable. Profits from such trade are positive only as long as:

$$
\hat{\pi}_{N}^{T}>0 \Rightarrow t<\frac{1+c}{3} \equiv t_{0} .
$$

Accordingly, if $t \geqslant t_{0}$, there is duopoly between a regional firm and the foreign firm in each country, and no intra-regional trade. In this case, a regional firm's profits are:

$$
\hat{\pi}_{R}^{D}=\frac{(1+c)^{2}}{9},
$$

while those of the foreign producer are:

$$
\hat{\pi}_{F}^{D}=2 \frac{(1-2 c)^{2}}{9} .
$$

In this duopoly case, exports from the foreign firm are profitable if:

$$
\hat{\pi}_{F}^{D}>0 \Rightarrow c<\frac{1}{2} \equiv c_{2}
$$

For $c>c_{2}$, the foreign firm is not competitive (either due to high production costs or high international trade costs, or both); we can think about this as the pre-globalized situation.

\section{Strategic Regional Integration}

We assume that policies of regional integration are shaped by lobbying activities of the local producers. We are interested in the way globalization may affect the firms' profits and hence their willingness to lobby for a reduction in these trade costs. ${ }^{1}$ Define strategic regional integration as a reduction in

\footnotetext{
${ }^{1}$ We assume that it is not feasible to directly and unilaterally affect extra-regional trade costs, for instance due to multilaterally binding agreements like WTO regulations.
} 
intra-regional trade costs, $t$, such that (i) the foreign firm stays out, (ii) home firms' profits go up, and (iii) a similar reduction in $t$ prior to globalization would have led to a reduction in domestic firms' profits (implying that there would have been no lobbying for integration in that case). In other words, the aim of the lobbying is to keep the foreign firm out of the regional market, and the policy tool is regional integration such that the foreign firm finds exports unprofitable, that is, drives eq. (7) to zero. Since influencing policies is costly, and increasing in the level of policy change, the firms will aim for the minimal reduction in intra-regional trade costs such that the foreign producer stays out.

Two points should be noted with respect to strategic regional integration. First, there is only room for strategic integration in the interval $c \in\left(\frac{1}{3}, \frac{1}{2}\right)=$ $\left(c_{0}, c_{2}\right)$, i.e. when competition from the foreign firm is neither too low nor too high. In fact, the upper bound is due to the fact that if $c>c_{2}$, then the foreign firm does not export even in the absence of intra-regional trade. The lower bound is due to the fact that $c<c_{0}$ would make it impossible to block out the foreign firm by the means of regional integration alone; this can be seen from the fact that for $c=\frac{1}{3}, t^{*}=0$.

The first question we need to address in order to investigate the room for strategic regional integration is: What is the impact of reducing trade costs to $t^{*}$ prior to globalization. From (3), we find that the regional firms are indifferent between staying at $t$ and reducing trade costs to $t^{*}$ when the following equality holds:

$$
\pi_{R}^{D}(t)=\pi_{R}^{D}\left(t^{*}\right) \Leftrightarrow t=\frac{7}{5}-3 c \equiv t_{1}
$$

Hence, for $t \geq t_{1}$, the regional firms gain from integration to $t^{*}$ prior to globalization, while for $t<t_{1}$, they lose. 
Next, we consider the same question in a globalized economy. Consider first the case where globalization leads to triopoly competition, that is, $t<t_{0}$. The regional firms' triopoly profits are then given by $\hat{\pi}_{R}^{T}$. With strategic integration, their profits are given by $\pi_{R}^{D}\left(t^{*}\right)$. The regional firms are indifferent between competing with the foreign firm with trade costs $t>t^{*}$ and a regional duopoly with trade costs at $t^{*}$ when the following equation holds:

$$
\hat{\pi}_{R}^{T}(t)=\pi_{R}^{D}\left(t^{*}\right) \Leftrightarrow t=\frac{7-13 c}{5} \equiv t_{2} .
$$

Hence, for $t>t_{2}$, the regional firms gain from integration to $t^{*}$, while for $t \leq t_{2}$, they lose from integration to $t^{*}$. We note that $t_{1}>t_{2}$ : in other words, there exist levels of trade costs such that the regional firms would gain from a reduction in trade cost to $t^{*}$ only under globalization. We have thus established that there is room for strategic regional integration in the situation where globalization is associated with triopoly competition.

Consider next the case where globalization leads to duopoly competition, that is $t \geq t_{0}$. We find that regional firms are indifferent between accepting globalization at trade costs $t>t^{*}$ and lowering trade costs to $t^{*}$ when the following equation holds:

$$
\hat{\pi}_{R}^{D}=\pi_{R}^{D}\left(t^{*}\right) \Rightarrow c=\frac{4}{11} \equiv c_{3} .
$$

For $c<c_{3}$, the regional firms gain from integration to $t^{*}$, while for $c \geqslant c_{3}$, they lose. It can be shown that in the pre-globalization scenario, the regional firms would have lost from a reduction in trade costs in this case. Again, we find that there is room for strategic regional integration, this time when the absence of policy would result in duopoly competition between the local firm and the foreign firm.

Figure 2 summarizes the above results. The regions for strategic regional integration are marked by $A$ and $B$, where $A$ gives the case where the alter- 
native to a strategic policy is triopoly competition, while $B$ gives the case where the alternative is duopoly competition.

The figure shows that the potential for strategic regional integration depends on the interplay between the competitiveness of a new entrant and ex-ante regional trade costs. First, we observe that when the foreign firm is highly competitive, $c<c_{0}$, it is not possible to block entry through measures of regional integration. Hence, a necessary conditition for strategic regional integration is that the competitor is not too competitive. Second, we note that when external competition is very weak, it is not profitable to block entry through strategic integration; see area above $c_{1}$ and $t_{2}$. Intuitively, the regional firms prefer competing against a less efficient foreign firm rather than face intensified regional competition due to lower regional trade costs. Third, and following the two observations above, strategic regional integration applies when the foreign producer is moderately competive, either because of a relatively low $c$ (see area $B$ in Figure 2) and/or a relatively high ex-ante level of intra-regional trade costs $t$ (see area $A$ in Figure 2).

\section{Concluding Remarks}

Globalization poses new challenges to producers in developed economies. If "de-globalization" is not possible, for instance because it is not viable or too costly to introduce tariff and non-tariff barriers under WTO regulations, then deeper regional integration may create "shield" or "fortress-Europe" effect. In particular, we analyse the possibilities for a strategic deepening of regional integration, influenced by producer interests, under a globalization scenario in order to block the entry of foreign competitors in oligopolistic markets. We demonstrate that the competitiveness of the foreign entrant matters for the incentive to deepen regional integration: strategic regional integration is 
possible and profitable when the foreign firm is moderately competitive, i.e., external pressure is neither too high nor too low.

In our simple framework we consider asymmetries only between regional firms and the external competitors. We also assume that the two countries in the region are identical. Incorporating some asymmetries, for example, differences in market sizes and/or costs, might further enrich the analysis and allow us to investigate more realistic scenarios. These issues are left for future research.

\section{$5 \quad$ References}

Baldwin, R. (1995), "A domino theory of regionalism," in Baldwin, R., Haaparanta, P., and Kiander, J. (eds), Expanding Membership of the EU, Cambridge UK: Cambridge University Press, Cambridge Books: pp. 25-48.

Baldwin, R. (2006), "Multilateralising regionalism: spaghetti bowls as building blocs on the path to global free trade," The World Economy, 29(11): pp. 1451-1518.

Bhagwati, J. (1992), "Regionalism vs. multilateralism," The World Economy 15(5): pp. 535-556.

Bond, E.W., Syropoulos C. and L.A. Winters (2001), "Deepening of regional integration and multilateral trade agreements," Journal of International Economics 53: pp. 335-361.

Brander, J. and Krugman, P. (1983), “A 'reciprocal dumping' model of international trade," Journal of International Economics 15: pp. 313-321.

Capling, A. (2008), "Preferential trade agreements as instruments of foreign policy: an Australia-Japan FTA and its implications for the Asia Pacific region," The Pacific Review 21(1): pp. 27-44.

Freund, C. (2000), "Multilateralism and the endogenous formation of 
preferential trade agreements," Journal of International Economics 52: pp. 359-376.

Maggi, G. and Rodriguez-Clare, A. (1998), "The value of trade agreements in the presence of political pressures," Journal of Political Economy 106(3): pp. 574-601.

Martyn W. (2016), Major tech companies spend millions more on lobbying in 2015, CIO, 21 january 2016, pp. 12

Neary, P. (2004), "Foreign Direct Investments and the Single Market", The Manchester School, 70(3): 291-314.

Ossa, R. (2010), "A 'new trade' theory of GATT/WTO negotiation," NBER Working Papers No. 16388, National Bureau of Economic Research (NBER), Cambridge MA.

Solis M. (2013), Business advocacy in Asian PTAs: a model of selective corporate lobbying with evidence from Japan, Business and Politics, 15(1): $87-116$

Terada T. (2010), The Origins of ASEAN+6 and Japan's initiatives: China's rise and the agent-structure analysis, The Pacific Review, 23(2): 71-92.

Viner, J. (1950), The customs union issue, New York: Carnegie Endowment for International Peace.

White, G. W. (2005), "Free trade as a strategic instrument in the war on terror? The 2004 US-Maroccan free trade agreement," Middle East Journal 59(4): pp. 597-616. 


$$
.4
$$




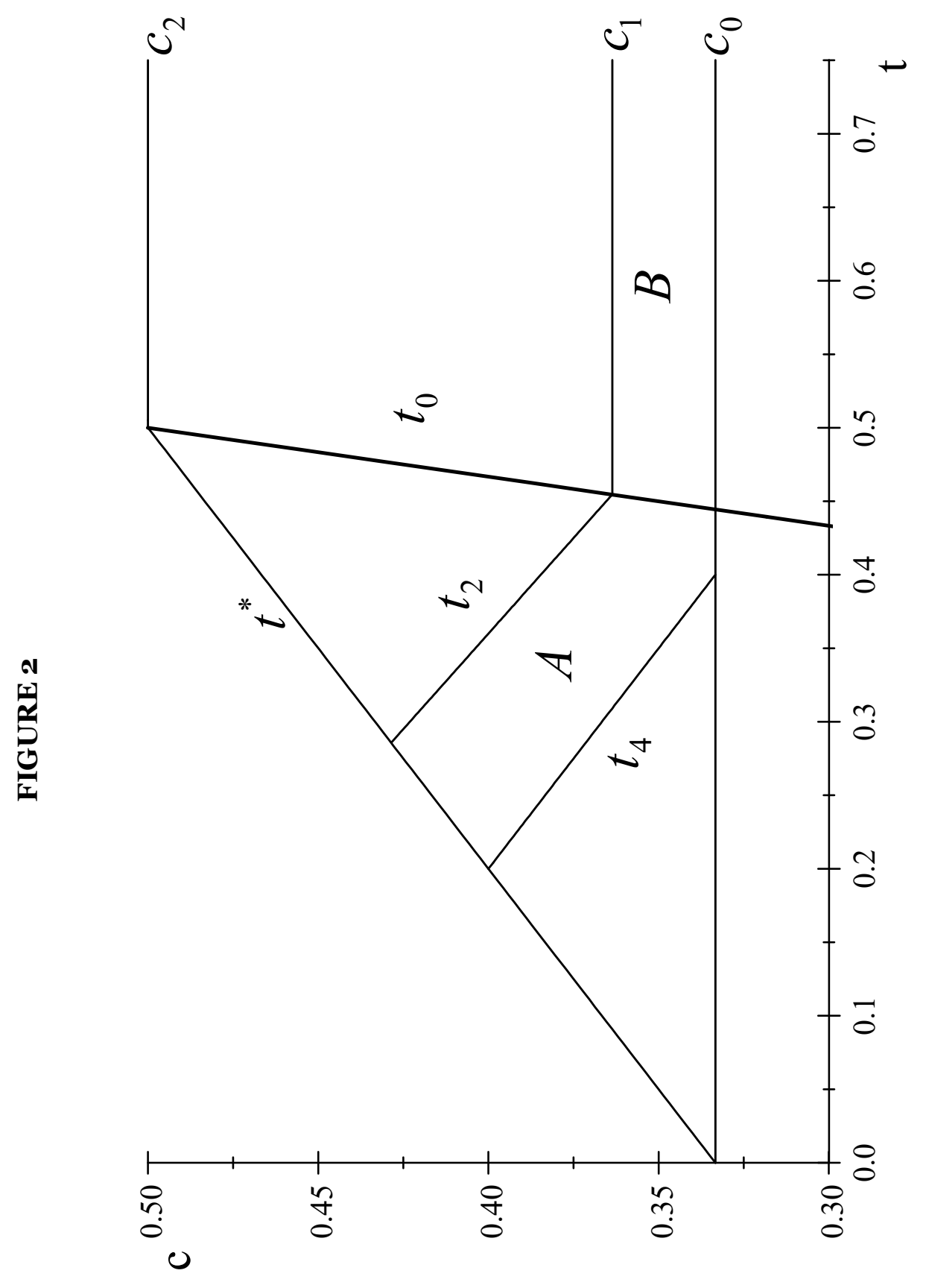

